\title{
Zinc and selenium supplement mitigated valproic acid-induced testis toxicity by modulating the oxidative redox balance in male rats
}

\author{
Maloos Naderi ${ }^{1,2}$, Nematollah Ahangar ${ }^{3}$, Faezeh Badakhshan ${ }^{2}$, Maryam Ghasemi $^{4}$, Fatemeh Shaki ${ }^{1,5}$ \\ ${ }^{1}$ Pharmaceutical Sciences Research Center, Hemoglobinopathy Institute, Mazandaran University of Medical Sciences, Sari, ${ }^{2}$ Student Research \\ committee, Mazandaran University of Medical Sciences, Sari, ${ }^{3}$ Department of Pharmacology, School of Medicine, Guilan University of Medical \\ Sciences, Rasht, ${ }^{4}$ Immunogenetics Research Center, Faculty of Medicine, Mazandaran University of Medical Sciences, Sari, ${ }^{5}$ Department of Toxicology \\ and Pharmacology, Faculty of Pharmacy, Mazandaran University of Medical Sciences, Sari, Iran
}

\begin{abstract}
Valproic acid (VPA) is widely used antiepileptic agent which is associated with reproductive toxicity via impairment in oxidative redox. Zinc ( $\mathrm{Zn})$ and selenium (Se) are trace element with antioxidant effect that known to be essential for spermatogenesis. In the current study, the protective effect of co-administration of $\mathrm{Zn}$ and Se on VPA-induced reproductive toxicity in male rats was evaluated. Forty-eight male rats were divided into 8 groups of six $(n=6)$ : Control group (treated with normal saline); VPA only (250, 500, 1,000 mg/kg) group; VPA (500 mg/kg) plus Zn (2 mg/kg) group; VPA (500 mg/kg) plus Se $(1.5 \mathrm{mg} / \mathrm{kg})$ group; VPA (500 mg/kg) plus a combination of Zn and Se group; and VPA+vitamin E (20 mg/kg) group. The Animals were sacrificed after 28 days of treatment and sperm analysis was taken. Also, evaluation of oxidative stress markers including malondialdehyde (MDA), protein carbonyl (PC), glutathione (GSH) and histopathological changes were done on testis tissue. Morphological changes and a significant decrease in motility and sperm count in rats treated with VPA were observed. Also, an increase in oxidative stress marker, including MDA and PC and a decrease in GSH level was evident in VPA group. Zn and Se administration was able to protect against sperm abnormality, ameliorate the histological change in testis tissue, and suppressed the increase in oxidative stress markers induced by VPA. These results indicated that combination therapy with $\mathrm{Zn}$ and Se showed better an ameliorative effect than each one alone. Therefore, it can be suggested as an effective supplement for reproductive impairment in VPA-treated patient.
\end{abstract}

Key words: Valproic acid, Testis toxicity, Oxidative stress, Zinc, Selenium

Received October 28, 2020; Revised July 2, 2021; Accepted July 12, 2021

\section{Introduction}

Infertility is one of the main health problems in human

\section{Corresponding author:}

Fatemeh Shaki iD

Department of Toxicology and Pharmacology, Faculty of Pharmacy, Mazandaran University of Medical Sciences, Sari 4847193698, Iran E-mail: fshaki.tox@gmail.com life, and nearly about $30 \%$ of this problem is related to dysfunction in the male reproductive system [1]. Spermatogenesis is a sensitive and complex process that various factors can disturb this process and lead to decline sperm quantity and quality and reduce male fertility [2]. One of the most common reasons of male infertility is long term use of some drugs [3].

Valproic acid (VPA) is a commonly prescribed antiepileptic agent which is used for widespread of neurologic disorder such as bipolar affective disorders and migraine [4-6]. 
Its pharmacologic action is mediated via an increase in the neurotransmitter level, such as $\gamma$-amino butyric acid and glutamate [7]. In spite of the high efficacy of VPA in the treatment of many neurological diseases, but VPA induced toxicity such as hepatotoxicity [8] and also male reproductive toxicity is a main concern for patients [9]. Previous studies showed the VPA can interfere with the male reproductive system function and lead to decrease of sperm count, motility and morphological abnormality [10]. However, limited studies investigated the mechanism VPA induced the male reproductive toxicity.

One of the most importantly suggested mechanisms is oxidative stress [10]. Oxidative stress occurred when there is an imbalance between the production and removal of reactive oxygen species (ROS) $[11,12]$. Previous studies showed that over production of ROS or significant depletion of antioxidant system (e.g., glutathione [GSH]) lead to oxidative damage in different tissue after VPA treatment $[12,13]$.

In addition, both animals [14] and human [15] studies revealed that VPA mediated male infertility is accompanied by increased oxidative stress in testis.

Zinc $(\mathrm{Zn})$ is known as the second most important trace metals in the body after iron. It has critical roles in human body as a structural component of proteins and as a cofactor in various enzymes especially antioxidant enzymes [16].

On the other hand, severe $\mathrm{Zn}$ depletion could increase oxidative stress biomarkers in rat plasma [17]. Interestingly, previous studies showed that the plasma level of $\mathrm{Zn}$ in VPAtreated rats was significantly depressed compared to control groups [17]. Several evidences supported the protective effect of $\mathrm{Zn}$ against oxidative damage to molecules, organelles, and cells in vitro and in vivo [18].

Selenium (Se) is a cofactor of glutathione peroxidase, which is a cyto-antioxidant enzyme. Se enhances the availability of GSH, which is one of the most abundant intrinsic antioxidants that help in preventing lipid peroxidation and the resulting cell damage [19].

Therefore, in this study, we investigated the protective effects of $\mathrm{Zn}$ and Se against VPA induce reproductive toxicity in male rats via assessment of oxidative stress parameter, semen analysis and pathology evaluation of testicular tissue.

\section{Material and Methods}

\section{Chemical and reagents}

Valproic acid sodium salt, sodium selenite $\left(\mathrm{Na}_{2} \mathrm{SeO}_{3}\right)$, and zinc sulfate were purchased from Sigma Aldrich (St. Louis, MO, USA). All other chemicals were of analytical grade and were purchased from standard commercial suppliers.

\section{Animals and treatments}

Male Wistar rats from our own breeding colony were used in the study (ethical code. IR.MAZUMS.REC.94-1764). The animals were caged individually and kept under standard laboratory conditions (temperature $25^{\circ} \mathrm{C} \pm 1^{\circ} \mathrm{C}$, natural lightdark cycle). The rats had free access to drinking water and commercial standard laboratory diet. Rats $(n=48)$ weighting approximately 220-250 g were randomly divided into $8 \mathrm{ex}$ perimental groups composed of six animals each, and treated as follows: Group 1 (control group) received normal saline; Group 2-4 received different dose of VPA (250, 500 and 1,000 $\mathrm{mg} / \mathrm{kg}$ ); Group 5 received (VPA $500 \mathrm{mg} / \mathrm{kg}+\mathrm{Zn} 2 \mathrm{mg} / \mathrm{kg}$ ); Group 6 received (VPA $500 \mathrm{mg} / \mathrm{kg}+\mathrm{Se} 1.5 \mathrm{mg} / \mathrm{kg}$ ); Group 7 received (VPA $500 \mathrm{mg} / \mathrm{kg}+$ combination of $\mathrm{Zn}+\mathrm{Se}$ ); Group 8 received (VPA+vitamin E $20 \mathrm{mg} / \mathrm{kg}$ as a positive control) by gavage for 28 consecutive days.

\section{Measurement of lipid peroxidation}

Lipid peroxidation (LPO) was measured in the testes tissue using thiobarbituric acid reacting substance and was expressed in terms of malondialdehyde (MDA) content. Sample aliquots were incubated with $10 \%$ trichloroacetic acid and $0.67 \%$ thiobarbituric acid. The mixture was heated in a boiling water bath for 30 minutes, an equal volume of nbutanol was added, and the final mixture was centrifuged. The absorbance of the samples was determined at $532 \mathrm{~nm}$. The results were expressed as $\mu \mathrm{M}$ MDA [12].

\section{Measurement protein carbonyl in testis and epididymides}

Protein carbonyl content was measured by a method based on the reaction of carbonyls with 2,4-dinitrophenylhydrazine forming dinitro phenyl hydrazone, a yellow compound. The standard curve was prepared by using different bovine serum albumin concentrations and the slope was used to express the levels of carbonyl protein as $\mu \mathrm{M}$ protein [20].

\section{Measurement of glutathione}

Content GSH content was determined using 5,5-dithiobis (2-nitrobenzoic acid) as the indicator and the developed yellow color was read at $412 \mathrm{~nm}$ on a spectrophotometer [21]. 


\section{Sperm count and motility assay}

The epididymal sperm suspension was prepared in $1 \mathrm{ml}$ of phosphate buffered saline (PBS) at $\mathrm{pH} 7.2$ and incubated at $32^{\circ} \mathrm{C}$ for 10 minutes. An aliquot from the suspension $(1 \mathrm{ml})$ was diluted in a ratio of 1:40 with PBS. A sample of the diluted suspension was charged into a hemocytometer. The total sperm count in eight squares (except the central erythrocyte area) of one $\mathrm{mm}^{2}$ each was determined and multiplied by $5 \times 104$ to get the total count [22]. Then the same eight squares were also examined for motile sperms and the percentage of motile sperm were recorded [23].

\section{Sperm morphology assay}

A fine epididymal sperm suspension was made and stained with $0.2 \mathrm{ml}$ of $1 \%$ aqueous eosin. About one drop of stained suspension was placed on a clean slide and was dried. Slides were examined for abnormalities in five hundred sperms per animal and were classified into normal and abnormal sperms. Further, the abnormal sperms were designated under head abnormalities and tail abnormalities. The head abnormalities were further sub-grouped as amorphous, hookless and banana shaped, and the tail abnormalities as coiled/folded and broken [22, 23].

\section{Histopathological assay}

The left testis were removed and fixed at $4 \%$ buffered formaldehyde solution for 24 hours for histological examination. The samples were embedded in paraplast, cut into 5

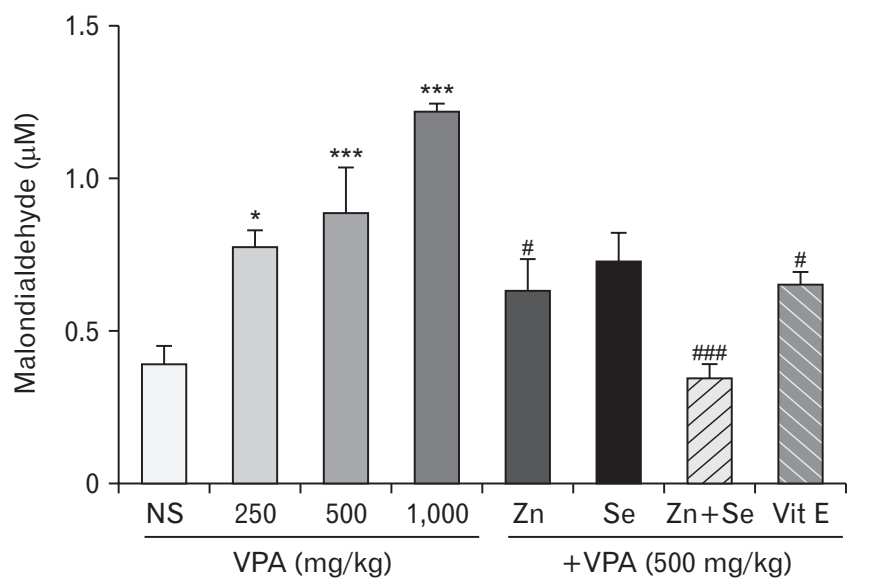

Fig. 1. Effects of Selenium (Se) and Zinc (Zn) on valproic acid (VPA)induced lipid peroxidation in testis tissue. Data were expressed as mean. NS, normal salin (control group); Vit E, vitamin E. ${ }^{*} P<0.05$ compared to control. ${ }^{* *} P<0.001$ compared to control. ${ }^{*} P<0.05$ compared to VPA $(500 \mathrm{mg} / \mathrm{kg}) .{ }^{\# \# \#} P<0.001$ compared to VPA $(500$ $\mathrm{mg} / \mathrm{kg})$. mm thick sections and stained with hematoxylin and eosin (H\&E) for light microscopic evaluation. Six aleatory fields of each section of the testis were qualitatively analyzed [9]. Spermatogenesis was assessed using the Johnsen scoring system [24].

\section{Statistical analysis}

Results are presented as mean \pm standard deviation from six times assay. All statistical analyses were performed using the SPSS software (version 13; SPSS Inc., Chicago, IL, USA) and one-way ANOVA test, followed by the post hoc Tukey test was used. Statistical significance was set at $P<0.05$.

\section{Results}

\section{Effects of zinc and selenium on lipid peroxidation in rat testis}

MDA levels were significantly increased in VPA-treated rats compared to control group. We observed significant differences in MDA concentration between VPA+Zn and $\mathrm{VPA}+$ combination of $\mathrm{Zn}$ and Se compared to VPA (500 mg)treated rats (Fig. 1).

\section{Effects of zinc and selenium on protein carbonyl in rat testis}

The protein concentration was found to be increased as a consequence of oxidative stress in VPA (500 mg)-treated rats compared with the control group. Significant difference in

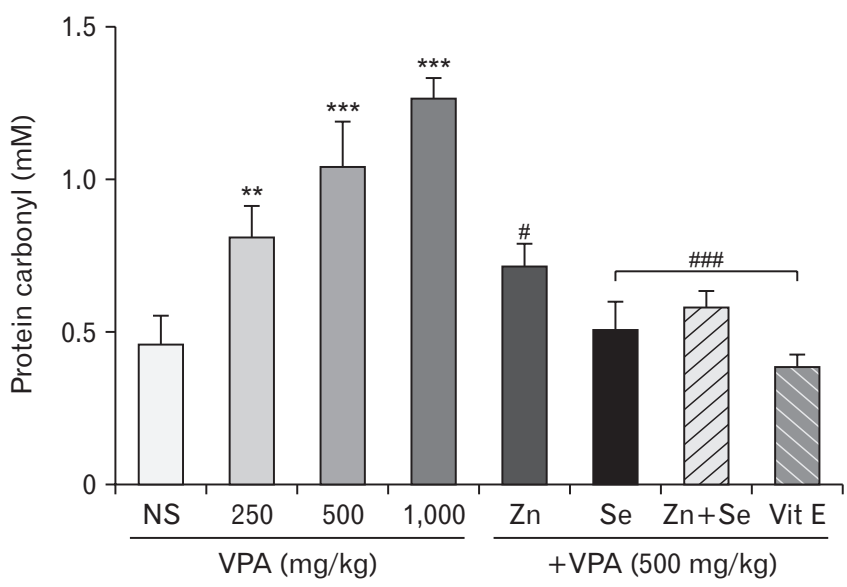

Fig. 2. Effects of Selenium (Se) and Zinc ( $\mathrm{Zn}$ ) on valproic acid (VPA)induced protein carbonyl in testis tissue. Data were expressed as mean. NS, normal salin (control group); Vit E, vitamin E. ${ }^{* *} P<0.01$ compared to control. ${ }^{* *} P<0.001$ compared to control. ${ }^{*} P<0.05$ compared to VPA $(500 \mathrm{mg} / \mathrm{kg}) .{ }^{\# \# \#} P<0.001$ compared to VPA $(500$ $\mathrm{mg} / \mathrm{kg})$. 
protein carbonyl concentration between $\mathrm{VPA}+\mathrm{Zn}$, VPA+Se, and VPA+combination of $\mathrm{Zn}$ and Se groups compared to VPA-treated rats were observed. Also, the Administration of Se and combinations of $\mathrm{Zn}+$ Se showed significant difference in protein carbonyl concentration from the $\mathrm{Zn}$ alone (Fig. 2).

\section{Effects of zinc and selenium on glutathione in rat testis}

We yielded a significant decrease in GSH level after VPA administration. Also, co-administration of $\mathrm{Zn}$ and Se showed significant difference in GSH concentration of Se or Zn alone (Fig. 3).

\section{Effects of zinc and selenium on sperm motility}

Spermatozoa motility decreased in rats treated with VPA compared to control groups, while co-administration of $\mathrm{Zn}+\mathrm{Se}, \mathrm{Zn}$ and Se alone showed significant difference in sperm motility compared to VPA-treated groups (Table 1).

\section{Effects of zinc and selenium on sperm morphology}

Light microscopical analysis testicular sections assessed qualitative morphology sperm cells. Sperm morphology affected in rats treated with VPA compared to control groups, while co- administration of $\mathrm{Zn}+\mathrm{Se}$, Se and $\mathrm{Zn}$ alone significantly restore the altered (Table 1).

\section{Effects of zinc and selenium on sperm count}

Sperm concentration was affected by treatment with VPA, the combination of $\mathrm{Zn}+\mathrm{Se}$, Se and $\mathrm{Zn}$ alone increased sperm count, but showed no significant difference in sperm count

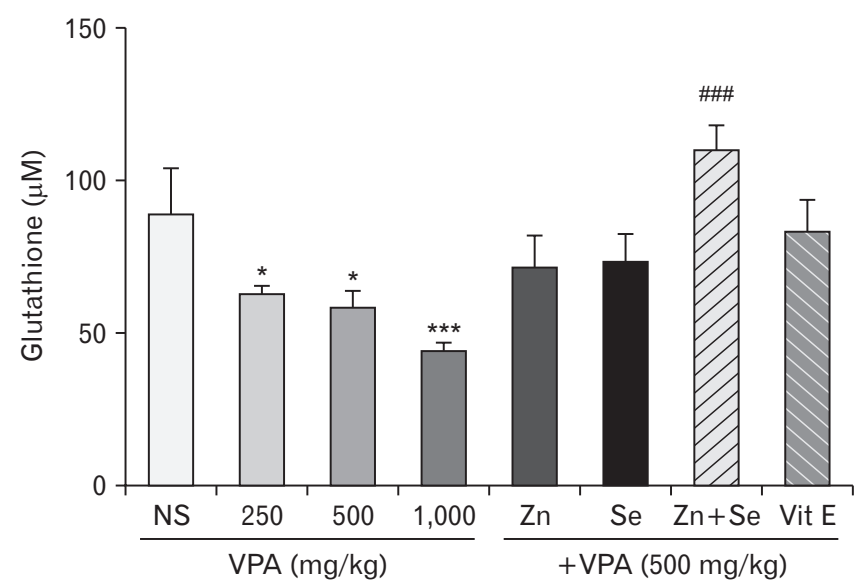

Fig. 3. Effects of Selenium (Se) and Zinc ( $\mathrm{Zn}$ ) on valproic acid (VPA)induced GSH oxidation in testis tissue. Data were expressed as mean. NS, normal salin; Vit E, vitamin E. ${ }^{*} P<0.05$ compared to control. ${ }^{* * *} P<0.001$ compared to control. ${ }^{\# \# *} P<0.001$ compared to VPA $(500 \mathrm{mg} / \mathrm{kg})$. compared to VPA-treated groups (Table 1).

\section{Histopathological examination}

The histological appearance of the testicular tissues of the control group was normal in appearance (Fig. 4A). VPA induced histopathological variations in the testis such as decrease in germinal cell layer thickness (Fig. 4B), vacuolization and degenerative changes in germinal cells (Fig. 4C), impaired spermatogenesis, stop maturation in some parts (Fig. 4D), increase in leydig cells (Fig. 4E) An improvement was showed in the groups which received combination of $\mathrm{Zn}$ and $\mathrm{Se}$, thus showing its protective action (Fig. $4 \mathrm{~F}-\mathrm{H}$ ).

Spermatogenesis was evaluated using the Johnsen scoring system (Table 2).

\section{Discussion}

VPA is frequently used for the treatment of various epileptic states, but its side effect such as reproductive toxicity limited its use [25]. It has been well shown that abnormalities in the sperm analysis were seen in patients treated with VPA [26].

On the other hand, in animal studies, oral administration of VPA for 60 days in rats significantly decreased testicular weight, sperm cell concentration, live sperms, and percentage of progressively motile spermatozoa and increased percentage of morphologically abnormal spermatozoa [27].

The mechanism by which VPA treatment leads to impaired sperm quality has not been completely known. An increasing of evidence suggested that oxidative stress may be involved in VPA testis toxicity [28].

Table 1. Effects of VPA on sperm parameters

\begin{tabular}{lccc}
\hline \multicolumn{1}{c}{ Group } & $\begin{array}{c}\text { Sperm } \\
\text { abnormality }(\%)\end{array}$ & $\begin{array}{c}\text { Sperm } \\
\text { motility }(\%)\end{array}$ & $\begin{array}{c}\text { Sperm } \\
\text { count }\left(\times 10^{6} / \mathrm{ml}\right)\end{array}$ \\
\hline NS & $13.6 \pm 3$ & $94.1 \pm 1$ & $39 \pm 4$ \\
VPA & $47 \pm 4^{\text {a) }}$ & $71 \pm 1^{\text {a) }}$ & $24.3 \pm 2.5^{\text {a) }}$ \\
VPA+Se & $35 \pm 3^{\text {c) }}$ & $85.3 \pm 1.5^{\text {d) }}$ & $26 \pm 3$ \\
VPA+Zn & $34.2 \pm 3^{\text {c }}$ & $84 \pm 1^{\text {d) }}$ & $26.6 \pm 4$ \\
VPA+(Zn+Se $)$ & $30.8 \pm 3^{\text {d) }}$ & $81.1 \pm 1^{\text {d) }}$ & $26.6 \pm 2.5$ \\
VPA+Vit E & $10 \pm 3^{\text {d) }}$ & $81.7 \pm 0.7^{\text {d) }}$ & $34 \pm 2^{\text {b) }}$ \\
\hline
\end{tabular}

Values are presented as mean \pm SD. VPA, valproic acid; Se, selenium; Zn, zinc; Vit E, vitamin E. Sperm morphology, motility and count were evaluated in control (normal saline), VPA, VPA+Se, VPA+Zn, VPA+Zn+Se and VPA+Vit E groups. ${ }^{\text {a) }}$ Significantly different from control group $(P<0.001) .{ }^{\text {b) }}$ Significantly different from VPA-treated group $(P<0.05)$. ${ }^{c}$ Significantly different from VPA-treated group $(P<0.01) .{ }^{\mathrm{d}}$ Significantly different from VPA-treated group $(P<0.001)$ 

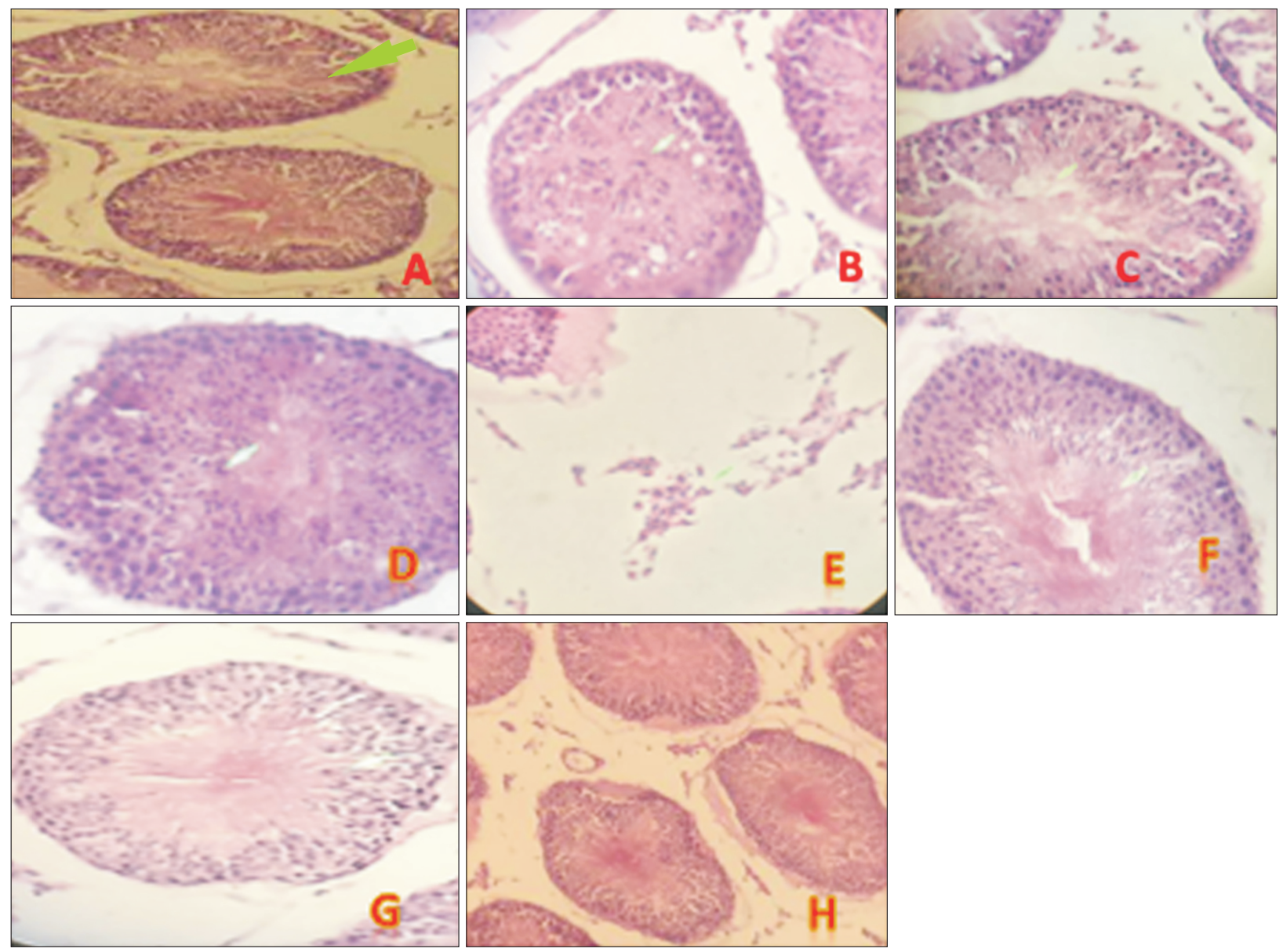

Fig. 4. H\&E-stained testis histology pictures (with $\times 40$ objective lens) showing normal testis. Morphology (control) (A), VPA-treated groups showed a decrease in germinal cell layer thickness (B), degenerative. changes and vacuolization in germinal cells (C), impaired spermatogenesis, stop maturation in some parts (D), increase in leydig cells (E). VPA+Zn-treated group (F), and VPA+Se-treated group (G) showed a normal germinal cell layer thickness and improve maturation. $(\mathrm{H}) \mathrm{VPA}+\mathrm{Zn}+\mathrm{Se}$-treated groups (combination therapy) showed better effect than $\mathrm{Zn}$ and Se alone. VPA, valproic acid; Zn, zinc; Se, selenium.

Table 2. Effects of $\mathrm{Zn}$ and Se on testicular weight and histology

\begin{tabular}{lrrrrrr}
\hline \multicolumn{1}{c}{ Parameter } & NS & VPA & VPA+Se & VPA+Zn & VPA+Sn+Zn & VPA+Vit E \\
\hline Testicular weight $(\mathrm{g})$ & $1.65 \pm 0.09$ & $1.36 \pm 0.11^{\mathrm{a})}$ & $1.56 \pm 0.06^{\mathrm{c}}$ & $1.59 \pm 0.08^{\mathrm{d})}$ & $1.63 \pm 0.05^{\mathrm{e}}$ & $\left.1.54 \pm 0.07^{\mathrm{b}}\right)^{\mathrm{a}}$ \\
Johnson score & $9.3 \pm 0.74$ & $4 \pm 0.57^{\mathrm{a})}$ & $5.8 \pm 0.68^{\mathrm{c})}$ & $7 \pm 0.81^{\mathrm{e})}$ & $8.3 \pm 0.74^{\mathrm{e}}$ & $6.3 \pm 0.74^{\mathrm{d})}$ \\
\hline
\end{tabular}

Values are presented as mean \pm SD. NS, normal salin (control group); PA, valproic acid; Se, selenium; Zn, zinc; Sn, selenium; Vit E, vitamin E. Johnsen score scale of 10 to 1: 10, normal spermatogenesis with open lumen; 9 , many spermatozoa with obliteration of lumen; 8, only a few sprmtozoa; 7, no spermatozoa but many spermatids present; 6 , no spermatozoa and only a few spermatids; 5 , no sperms/spermatids but several sprmatocytes; 4 , only a few spermatocytes present;

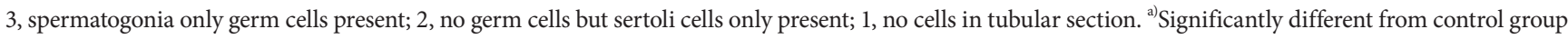
$(P<0.0001) .{ }^{\text {b) }}$ Significantly different from VPA-treated group $(P<0.05) .{ }^{c}$ Significantly different from VPA-treated group $(P<0.01) .{ }^{\text {d) }}$ Significantly different from VPA-treated group $(P<0.001) .{ }^{\text {e) }}$ Significantly different from VPA-treated group $(P<0.0001)$.

Some organs such as testis known to be particularly sensitive to oxidative stress and can lead to significant damage in this tissue [29]. In fact, both the testis and the sperm cells are rich in polyunsaturated fatty acids, which make them susceptible to ROS attack and consequently result in oxidative damage [30-32]. We observed an increase of LPO, protein carbonyl level and significant decrease of GSH content as indicators of oxidative damage to cellular macromolecules after VPA treatment in rat testis.

Therefore, this study confirmed the role of oxidative dam- 
age in VPA induced reproductive toxicity.

In addition, VPA induced histopathological changes such as a decrease in germinal cell layer thickness, degenerative changes in germinal cells, vacuolization in Sertoli cells, impaired spermatogenesis, stop maturation in some parts, increase in Leydig cells and impaired spermatogenesis in testis tissue of rats (Fig. 4).

This study has demonstrated significant effects of $\mathrm{Zn}$ and Se on rat spermatogenesis. As shown by the Johnsen scores, VPA toxicity is related with impaired spermatogenesis, On the other hand, $\mathrm{Zn}$ and Se supplementation is related with amelioration of the impairment induced by VPA toxicity, thus resulting in a higher Johnsen score and obviously, normal spermatogenesis (Table 1).

Also, morphological changes and decrease in motility and sperm count in rats treated with VPA were observed. Previous studies showed that $\mathrm{Zn}$ concentration of plasma was significantly decreased after chronic VPA treatment. So, Zn deficiency may be considered as a mechanism involved in oxidative damage due to VPA therapy [33]. Several evidences demonstrated a protective role of $\mathrm{Zn}$ against oxidative damage to molecules, organelles, and cells in vitro [18]. Interestingly, Bedwal et al. [34] reported that prostate has a higher $\mathrm{Zn}$ content than any other organ of the human body.

Indeed, it was shown that $\mathrm{Zn}$ deficiency leads to gonadal dysfunction, decreased weight of testes and caused shrinkage of seminiferous tubules [34]. A recent study has shown that $\mathrm{Zn}$-deficient in the diet paves promote the cell damage in the rat testis. Moreover, $\mathrm{Zn}$-deficiency increases LPO in various rat tissues, while the $\mathrm{Zn}$ supplementation restored this impairment [35]. On the other hand, the administration of high dose of $\mathrm{Zn}$ prevented tissue damage due to various toxic agents such as acetaminophen, bromobenzene, carbon tetrachloride, pesticide, nickel, endotoxin and cadmium [3539].

In our study, $\mathrm{Zn}$ administration restore the impairment of sperm motility and morphological changes and improve pathological changes in testis tissue. Also, oxidative stress markers in testis tissue of VPA-treated rats significantly reduced by $\mathrm{Zn}$ administration. Therefore, the antioxidant effect of $\mathrm{Zn}$ can be considered as a possible protective mechanism against VPA induced testis toxicity.

Moreover, Se is another trace elements in all biological systems such as reproduction and its antioxidant effects have well known [40]. Testis and epididymis contain excessive concentrations of Se which demonstrating its important role during spermatogenesis for improvement of semen quality. Also, this study showed Se ameliorated VPA-induced oxidative stress in the testis tissue. On the other hand, VPA induced pathological changes in testis tissue as well as abnormalities in the sperm analysis restored after administration of Se.

In this study, we observed $\mathrm{Zn}$ and Se administration considerably inhibited oxidative stress in VPA-treated rats. Interestingly, determination of sperm count, motility and morphological changes which are sensitive biomarkers of testicular damage showed that co-administration of $\mathrm{Zn}$ and Se has a better effect than each one alone against VPA-induced sperm abnormality. This study demonstrated that VPA treatment caused oxidative damage and spermatogenesis abnormalities in rat testis tissue. Also, $\mathrm{Zn}$ and Se administration ameliorated these disturbances caused by VPA, whereas Se and $\mathrm{Zn}$ together exert a better effect against the observed oxidative stress and reproductive toxicity induced by VPA. Therefore, use of $\mathrm{Zn}$ and Se supplement can be suggested for attenuation of the side effects of VPA therapy.

\section{ORCID}

Maloos Naderi: https://orcid.org/0000-0002-5440-3513

Nematollah Ahangar:

https://orcid.org/0000-0001-7712-8537

Faezeh Badakhshan:

https://orcid.org/0000-0002-2203-9307

Maryam Ghasemi:

https://orcid.org/0000-0001-6985-6876

Fatemeh Shaki: https://orcid.org/0000-0001-5861-656X

\section{Author Contributions}

Conceptualization: NA, FS. Data acquisition: MN, FB. Data analysis or interpretation: MG, FS. Drafting of the manuscript: MN, FB. Critical revision of the manuscript: NA, FS. Approval of the final version of the manuscript: NA, FS.

\section{Conflict of Interest}

No potential conflict of interest relevant to this article was reported. 


\section{Acknowledgements}

The article was extracted from Pharm.D. Thesis of Faezeh Badakhshan and supported by a grant (no. 1764) from the research council of Mazandaran University of Medical Sciences, Sari, Iran (ethical code: IR.MAZUMS.REC.94-1764).

\section{References}

1. Isidori AM, Pozza C, Gianfrilli D, Isidori A. Medical treatment to improve sperm quality. Reprod Biomed Online 2006;12:70414.

2. Bener A, Al-Ansari AA, Zirie M, Al-Hamaq AO. Is male fertility associated with type 2 diabetes mellitus? Int Urol Nephrol 2009;41:777-84.

3. Jungwirth A, Giwercman A, Tournaye H, Diemer T, Kopa Z, Dohle G, Krausz C. European Association of Urology guidelines on male infertility: the 2012 update. Eur Urol 2012;62:32432.

4. Emekli-Alturfan E, Alev B, Tunali S, Oktay S, Tunali-Akbay T, Ozturk LK, Yanardag R, Yarat A. Effects of edaravone on cardiac damage in valproic acid induced toxicity. Ann Clin Lab Sci 2015;45:166-72.

5. Blumenfeld A, Gennings C, Cady R. Pharmacological synergy: the next frontier on therapeutic advancement for migraine. Headache 2012;52:636-47.

6. Soares-Weiser K, Bravo Vergel Y, Beynon S, Dunn G, Barbieri M, Duffy S, Geddes J, Gilbody S, Palmer S, Woolacott N. A systematic review and economic model of the clinical effectiveness and cost-effectiveness of interventions for preventing relapse in people with bipolar disorder. Health Technol Assess 2007;11:iiiiv, ix-206.

7. Bialer M. Why are antiepileptic drugs used for nonepileptic conditions? Epilepsia 2012;53 Suppl 7:26-33.

8. Lewis JH, Zimmerman HJ, Garrett CT, Rosenberg E. Valproate-induced hepatic steatogenesis in rats. Hepatology 1982;2:870-3.

9. Ourique GM, Saccol EM, Pês TS, Glanzner WG, Schiefelbein SH, Woehl VM, Baldisserotto B, Pavanato MA, Gonçalves PB, Barreto KP. Protective effect of vitamin E on sperm motility and oxidative stress in valproic acid treated rats. Food Chem Toxicol 2016;95:159-67.

10. Kose-Ozlece H, Ilık F, Cecen K, Huseyınoglu N, Serım A. Alterations in semen parameters in men with epilepsy treated with valproate. Iran J Neurol 2015;14:164-7.

11. Valko M, Leibfritz D, Moncol J, Cronin MT, Mazur M, Telser J. Free radicals and antioxidants in normal physiological functions and human disease. Int J Biochem Cell Biol 2007;39:4484.

12. Shokrzadeh M, Zamani E, Mehrzad M, Norian Y, Shaki F. Protective effects of propofol against Methamphetamine-induced neurotoxicity. Toxicol Int 2015;22:92-9.
13. Shaki F, Pourahmad J. Mitochondrial toxicity of depleted uranium: protection by Beta-glucan. Iran J Pharm Res 2013;12:13140.

14. Girish C, Shweta O, Raj V, Balakrishnan S, Varghese RG. Ellagic acid modulates sodium valproate induced reproductive toxicity in male Wistar rats. Indian J Physiol Pharmacol 2014;58:416-22.

15. Chen SS, Shen MR, Chen TJ, Lai SL. Effects of antiepileptic drugs on sperm motility of normal controls and epileptic patients with long-term therapy. Epilepsia 1992;33:149-53.

16. Ackland ML, Michalczyk A. Zinc deficiency and its inherited disorders- a review. Genes Nutr 2006;1:41-9.

17. Daffron JC, Kasarskis EJ. Effect of valproic acid on zinc metabolism in the rat. Toxicol Lett 1984;23:321-5.

18. Bray TM, Bettger WJ. The physiological role of zinc as an antioxidant. Free Radic Biol Med 1990;8:281-91.

19. Hsu PC, Guo YL. Antioxidant nutrients and lead toxicity. Toxicology 2002;180:33-44.

20. Dalle-Donne I, Rossi R, Giustarini D, Milzani A, Colombo R. Protein carbonyl groups as biomarkers of oxidative stress. Clin Chim Acta 2003;329:23-38.

21. Naderi M, Ahangar N, Shaki F. Zinc and selenium protects against sodium valproate induced nephrotoxicity through modulation of oxidative stress. J Mazandaran Univ Med Sci 2016;26:111-22.

22. Bairy L, Paul V, Rao Y. Reproductive toxicity of sodium valproate in male rats. Indian J Pharmacol 2010;42:90-4.

23. Narayana K. An aminoglycoside antibiotic gentamycin induces oxidative stress, reduces antioxidant reserve and impairs spermatogenesis in rats. J Toxicol Sci 2008;33:85-96.

24. Omu AE, Al-Azemi MK, Al-Maghrebi M, Mathew CT, Omu FE, Kehinde EO, Anim JT, Oriowo MA, Memon A. Molecular basis for the effects of zinc deficiency on spermatogenesis: an experimental study in the Sprague-dawley rat model. Indian J Urol 2015;31:57-64.

25. Khan S, Ahmad T, Parekh CV, Trivedi PP, Kushwaha S, Jena G. Investigation on sodium valproate induced germ cell damage, oxidative stress and genotoxicity in male Swiss mice. Reprod Toxicol 2011;32:385-94.

26. Isojärvi JI, Löfgren E, Juntunen KS, Pakarinen AJ, Päivänsalo M, Rautakorpi I, Tuomivaara L. Effect of epilepsy and antiepileptic drugs on male reproductive health. Neurology 2004;62:247-53.

27. Soliman GA, Abla A. Effects of antiepileptic drugs carbamazepine and sodium valproate on fertility of male rats. Dtsch Tierarztl Wochenschr 1999;106:110-3.

28. Hamza AA, Amin A. Apium graveolens modulates sodium valproate-induced reproductive toxicity in rats. J Exp Zool A Ecol Genet Physiol 2007;307:199-206.

29. Tomascik-Cheeseman LM, Coleman MA, Marchetti F, Nelson DO, Kegelmeyer LM, Nath J, Wyrobek AJ. Differential basal expression of genes associated with stress response, damage control, and DNA repair among mouse tissues. Mutat Res 2004;561:1-14. 
30. Agarwal A, Gupta S, Sikka S. The role of free radicals and antioxidants in reproduction. Curr Opin Obstet Gynecol 2006;18:325-32.

31. Aitken RJ, Baker MA. Oxidative stress, sperm survival and fertility control. Mol Cell Endocrinol 2006;250:66-9.

32. Aitken RJ, Roman SD. Antioxidant systems and oxidative stress in the testes. Oxid Med Cell Longev 2008;1:15-24.

33. Ahangar N, Naderi M, Noroozi A, Ghasemi M, Zamani E, Shaki F. Zinc deficiency and oxidative stress involved in valproic acid induced hepatotoxicity: protection by zinc and selenium supplementation. Biol Trace Elem Res 2017;179:102-9.

34. Bedwal RS, Bahuguna A. Zinc, copper and selenium in reproduction. Experientia 1994;50:626-40.

35. Amara S, Abdelmelek H, Garrel C, Guiraud P, Douki T, Ravanat JL, Favier A, Sakly M, Ben Rhouma K. Preventive effect of zinc against cadmium-induced oxidative stress in the rat testis.
J Reprod Dev 2008;54:129-34.

36. Cagen SZ, Klaassen CD. Protection of carbon tetrachlorideinduced hepatotoxicity by zinc: role of metallothionein. Toxicol Appl Pharmacol 1979;51:107-16.

37. Sidhu P, Garg ML, Dhawan DK. Protective role of zinc in nickel induced hepatotoxicity in rats. Chem Biol Interact 2004;150:199-209.

38. Malhotra A, Dhawan DK. Current view of zinc as a hepatoprotective agent in conditions of chlorpyrifos induced toxicity. Pestic Biochem Physiol 2014;112:1-6.

39. Alcorn JM, Fierer J, Chojkier M. The acute-phase response protects mice from $\mathrm{D}$-galactosamine sensitization to endotoxin and tumor necrosis factor-alpha. Hepatology 1992;15:122-9.

40. Ahsan U, Kamran Z, Raza I, Ahmad S, Babar W, Riaz MH, Iqbal Z. Role of selenium in male reproduction - a review. Anim Reprod Sci 2014;146:55-62. 